KATARZYNA MAJCHRZAK

Wydział Prawa Kanonicznego

Uniwersytetu Kardynała Stefana Wyszyńskiego w Warszawie

\title{
CODZIENNY I COTYGODNIOWY OKRES WYPOCZYNKU
}

Treść: Wstęp. - 1. Norma i rozkład czasu wolnego. - 2. Przerwa w pracy. - 3. Dobowe i tygodniowe normy czasu pracy. - 4. Czas pracy pracowników młodocianych. - 5. Limit pracy w godzinach nadliczbowych. - Zakończenie.

\section{Wstęp}

W konstrukcji prawnej stosunku pracy, zasadniczą rolę odgrywa czas pracy, który jest miarą pracy. Czas pracy wyznacza godziny dnia, tygodnia, roku i życia, które spędzamy w pracy, na stanowisku roboczym ${ }^{1}$. Stanowi on również, jeden z podstawowych mierników wysiłku psychofizycznego pracownika. Obowiązkiem pracownika jest bycie każdego dnia roboczego do dyspozycji pracodawcy, jednakże zdecydowanie nie może i nie powinno to wpływać negatywnie na biologiczne wymogi zapewnienia organizmowi wypoczynku. Przepisy prawa pracy starają się zachować kompromis między pracą a wypoczynkiem. Prawo formułuje jasne normy zabezpieczające prawo pracownika do wypoczynku².

\section{Norma i rozklad czasu wolnego}

Istotnym unormowaniem, przewidzianym w dziale szóstym kodeksu pracy, jest ustalenie okresu nieprzerwanego odpoczynku, który powinien mieć zapewniony każdy pracownik.

1 J. Pacho, Czas pracy, Warszawa 1986, s. 26.

2 M. Piotrowski, Prawo pracy, Poznań 2000, s. 289; W. Masewicz, Czas pracy, w: Nowe prawo pracy, red. R. Korolec - J. Pacho, Warszawa 1975, s. 293. 
Pracownikom przysługuje prawo do regularnych dobowych i tygodniowych okresów odpoczynku, o czym mowa w art. 132 i art. 133 kodeksu pracy. Pracownikowi przysługuje w każdej dobie prawo, do co najmniej 11 godzin nieprzerwanego odpoczynku. Stąd dopuszczalny wymiar czasu pracy w ciągu doby nie może przekraczać 13 godzin. Obowiązująca norma art. 132 determinuje rezygnację z maksymalnego limitu 4 godzin nadliczbowych na dobę ze względu na szczególne potrzeby pracodawcy. Na podstawie art. $132 \S 2$, omawiany okres dobowego odpoczynku, nie odnosi się do pracowników zarządzających w imieniu pracodawcy zakładem pracy oraz do przypadków konieczności prowadzenia akcji ratowniczej dla ratowania życia lub zdrowia ludzkiego, ochrony mienia lub środowiska albo usunięcia awarii. Jednakże osobom, którym skrócono 11 godzinny odpoczynek dobowy, należy zapewnić równoważny okres odpoczynku w okresie rozliczeniowym ${ }^{3}$.

Artykuł 133 kodeksu pracy gwarantuje pracownikom prawo, do co najmniej 35 godzinnego nieprzerwanego odpoczynku tygodniowego, który obejmuje, co najmniej 11 godzin nieprzerwanego odpoczynku dobowego. Zasadniczo odpoczynek ten powinien przypadać $\mathrm{w}$ niedzielę. Jedynie w sytuacji, gdy praca w niedzielę jest dozwolona, odpoczynek może wówczas przypadać w innym dniu niż niedziela 4 . Ustawodawca w art. $133 \S 2$ dopuszcza możliwość skrócenia nieprzerwanego tygodniowego odpoczynku, ale tylko wobec osób zarządzających zakładem pracy, lub w przypadkach konieczności prowadzenia akcji ratowniczej, jak również w przypadku zmiany pory wykonywania pracy przez pracownika $\mathrm{w}$ związku z jego przejściem na inną zmianę, zgodnie z ustalonym rozkładem czasu pracy - jednakże nie mniej niż do 24 godzin. Również ten odpoczynek powinien przypadać $\mathrm{W}$ niedzielę.

3 J. Wratny, Kodeks pracy. Komentarz, Warszawa 2013, s. 299; K. RączKa, Nowelizacja Kodeksu pracy, Praca i Zabezpieczenie Społeczne 10(2003), s. 4.

4 A. Soвczyк, Kilka uwag na tle nowelizacji czasu pracy, Praca i Zabezpieczenie Społeczne 12(2003), s. 23. 


\section{Przerwa w pracy}

Na prawo do wypoczynku składa się również prawo do przerw w pracy. Zgodnie z art. 134 kodeksu pracy, jeśli dobowy wymiar czasu pracy pracownika wynosi, co najmniej 6 godzin, wówczas przysługuje pracownikowi prawo do przerwy. Powinna ona trwać, co najmniej 15 minut i jest wliczana do czasu pracy. Przerwa w pracy oznacza, że pracownik może opuścić wyznaczone stanowisko pracy. Zwyczajowo uważa się, że jest to przerwa na spożycie posiłku, ale przysługuje ona niezależnie od celu w jakim pracownik ją wykorzysta ${ }^{5}$.

Warto w tym miejscu wspomnieć o możliwości wprowadzenia, jednej przerwy nie wliczanej do czasu pracy, w wymiarze nie przekraczającym 60 minut. Jest ona przewidziana w art. 141 kodeksu pracy i według zamiaru ustawodawcy, powinna być wykorzystana na spożycie posiłku lub załatwienie spraw osobistych. Pracownik jednak, nie traci do niej prawa, jeżeli wykonuje w tym czasie inne czynności, jak na przykład wypoczywa uprawiając sport ${ }^{6}$. Należy pamiętać, że za czas przerwy, o której mowa w art. 141, pracownikowi nie przysługuje wynagrodzenie. Nie ma natomiast przeszkód prawnych, aby pracodawca samodzielnie kształtujący zasady wynagradzania przewidział w swoich przepisach płacowych kompensatę finansową za czas przerwy ${ }^{7}$. Powstaje pytanie, jaki jest stosunek przerwy wliczanej do czasu pracy do przerwy nie wliczanej do czasu pracy? Są to dwie odrębne przerwy. Pierwsza z nich musi mieć miejsce, gdyż ma charakter obligatoryjnego uprawnienia pracowniczego. Druga, nie wliczana do czasu pracy, może być wprowadzona, ale nie musi, a zatem ma charakter fakultatywny. Przerwa wliczana do czasu pracy nie zmienia jego rozkładu, ponieważ wchodzi w skład np. ośmiu godzin pracy na dobę. Druga natomiast, zmienia rozkład czasu pracy, gdyż w przypadku godzinnej przerwy,

5 W. Muszalski, Kodeks pracy. Komentarz, Warszawa 2000, s. 597; Zob. B. KRzYśKOW - W. SANETRA, Zmiany $w$ kodeksie pracy $w$ aspekcie regulacji czasu pracy $w d y$ rektywie Wspólnoty Europejskiej, Praca i Zabezpieczenie Społeczne 10(1996), s. 12.

${ }^{6}$ K. JAŚKOWSKI - E. ManIEwSKa, Kodeks Pracy. Komentarz. Ustawy towarzyszace z orzecznictwem, Kraków 2003, s. 369; K. WALCZAK, Czas pracy i urlopy wypoczynkowe w uregulowaniach UE - część I, Monitor Prawa Pracy 5(2004), s. 130.

7 Por. T. ZiEliński, Kodeks Pracy. Komentarz, Warszawa 2003, s. 758. 
powoduje wydłużenie łącznego czasu poświęconego pracy do 9 godzin. Oczywiście w czasie przerwy pracownik nie jest zobowiązany przebywać na terenie zakładu pracy, ale w większości przypadków, w praktyce tak jest. Według Tadeusza Nycza przerwa w pracy, o której mowa $\mathrm{w}$ art. 141 dotyczy, zatrudnienia w pełnym rozmiarze czasu pracy. Wobec tego, autor uważa, iż wprowadzenie takiej przerwy w stosunku do pracowników zatrudnionych w niepełnym rozmiarze czasu pracy uznać trzeba zasadniczo za niedopuszczalne, chyba, że konkretny pracownik wyrazi na to zgodę. Wspomnieć również warto, o specjalnej przerwie dla osób niepełnosprawnych. Zgodnie z art. 17 ustawy z dnia 27 sierpnia 1997 roku o rehabilitacji zawodowej i społecznej oraz zatrudnianiu osób niepełnosprawnych (Dz.U. z 2011 r. Nr 127, poz. 721, z późn. zm.), prawo do przerwy na gimnastykę usprawniającą lub wypoczynek ma zapewnione, każda pracująca osoba niepełnosprawna. Czas przerwy wynosi 15 minut i jest wliczany do czasu pracy. Jednocześnie ustawodawca wyraźnie wskazuje, że przerwa ta nie narusza przepisu art. 134 kodeksu pracy. Warto podkreślić, że prawa do dodatkowej przerwy w pracy, o której mowa w art. 17 ustawy o rehabilitacji zawodowej (...) nie pochłaniają uprawnienia do innych szczególnych przerw w pracy (między innymi określonych w art. 145 $\S 1$, czy art. 187 kodeksu pracy), ponieważ uprawnienie to związane jest wyłącznie z niepełnosprawnością pracownika, a nie wynika z rodzaju pracy czy uprawnień związanych z macierzyństwem tj. do przerwy na karmienie dziecka piersią. Tym bardziej uprawnienie wynikające z art. 17 ustawy o rehabilitacji zawodowej (...) nie może być zrealizowane w ramach przerwy, o której mowa w art. 141 kodeksu pracy, ponieważ jest ona przeznaczona na spożycie posiłku lub załatwienie spraw osobistych i nie wlicza się jej do czasu pracy.

Przesłanką wprowadzenia przerw w pracy jest z jednej strony odpoczynek dla pracownika a z drugiej, co się z tym również łączy, wydajniejsza jego praca.

8 T. Nycz, Czas pracy od 1 stycznia 2003 r., Kraków - Tarnobrzeg 2002, s. 87. 


\section{Dobowe i tygodniowe normy czasu pracy}

Ustawodawca w kodeksie pracy nie wyjaśnił pojęcia czasu wypoczynku. Jednak po przystąpieniu Polski do Unii Europejskiej prawo europejskie staje się integralną częścią polskiego porządku prawnego. Prawo krajowe wyrastające $\mathrm{z}$ dyrektyw wspólnotowych, musi być stosowane $\mathrm{z}$ uwzględnieniem treści dyrektyw. Zatem prawo pracy obowiązujące w Polsce to zarówno przepisy kodeksu pracy, jak również prawo wspólnotowe i dlatego możemy sięgnąc do definicji wspólnotowych. Dyrektywa 2003/88/EC z dnia 4 listopada 2003 r. w sprawie niektórych aspektów organizacji czasu pracy ${ }^{9}$, w art. 2 zawiera definicje legalne podstawowych pojęć. Zgodnie z tym przepisem, czasem wypoczynku (rest period) jest każdy inny czas niż czas pracy, czyli czas, w którym pracownik nie pracuje ani nie pozostaje $\mathrm{w}$ dyspozycji pracodawcy ${ }^{10}$.

O wypoczynku decyduje to ile pracujemy. Dlatego należy przede wszystkim wiedzieć, kiedy można mówić o czasie pracy. Art. 128 § 1 kodeksu pracy definiuje to pojęcie, podając, że: „czasem pracy jest czas, w którym pracownik pozostaje w dyspozycji pracodawcy w zakładzie pracy lub w innym miejscu wyznaczonym do wykonywania pracy". Stąd czas oczekiwania na klienta w sklepie, czy też kierowcy czekającego na wyładunek pomimo, że w tym czasie nie wykonują konkretnej pracy, ale pozostają $\mathrm{w}$ dyspozycji pracodawcy, można nazwać czasem pracy ${ }^{11}$.

Wspólnotowa definicja czasu pracy wskazuje, że jest to okres, w którym pracownik pracuje, pozostaje do dyspozycji pracodawcy i wykonuje swoje czynności lub obowiązki, zgodnie z przepisami $\mathrm{i} /$ lub procedurami obowiązującymi $\mathrm{w}$ danym kraju ${ }^{12}$. Należy zwrócić

9 Directive 2003/88/EC of the European Parliament and of the Council of 4 November 2003 concerning certain aspects of the organisation of working time, Dziennik Urzędowy Wspólnot Europejskich nr L 299 z dnia 18 listopada 2003 r., s. 0009-0019.

${ }^{10}$ L. Florek, Czas pracy $i$ urlopy wypoczynkowe $w$ prawie europejskim, Praca i Zabezpieczenie Społeczne 2(1999), s. 13; A. M. ŚwiĄTKowski, Europejskie prawo socjalne, tom II, Warszawa 1999, s. 211; Zob. L. FloreK, Europejskie prawo pracy i ubezpieczeń społecznych, Warszawa 1996, s. 53.

${ }^{11}$ W. Muszalski, Prawo pracy, Warszawa 1997, s. 55.

${ }^{12}$ Por. M. Matey - Tyrowicz, Prawo pracy, Warszawa 1998, s. 252. 
uwagę, iż definicja czasu pracy w kodeksie pracy różni się od definicji prawa wspólnotowego. Albowiem w kodeksie pracy nie ma mowy o wykonywaniu swoich czynności lub obowiązków.

Ustawodawca polski zdefiniował także pojęcia doby i tygodnia. Pojęcie doby częściowo odpowiada dobie kalendarzowej, bowiem liczy ona kolejne 24 godziny, poczynając od godziny, w której pracownik rozpoczyna pracę zgodnie z obowiązującym go rozkładem czasu pracy. Mówiąc o tygodniu pracy, należy mieć na uwadze 7 kolejnych dni kalendarzowych, poczynając od pierwszego dnia okresu rozliczeniowego.

Określone dobowe i tygodniowe normy czasu pracy, mimo że nie wynika to bezpośrednio z przepisu, korespondują z pojęciem zatrudnienia pracownika w pełnym wymiarze czasu pracy. Dlatego pracownik zatrudniony w ramach pełnego etatu winien wypracować określone w kodeksie wielkości czasu pracy ${ }^{13}$. Ustawodawca w art. 129 wskazał zasadnicze parametry normy podstawowej i określił, że czas pracy nie może przekraczać 8 godzin na dobę i przeciętnie 40 godzin w przeciętnie pięciodniowym tygodniu pracy, w przyjętym okresie rozliczeniowym nie przekraczającym 4 miesięcy. Od zasady tej przewidziane są wyjątki, a mianowicie art. $129 \S 2$, art. 135 - 138, art. 143 i art. 144. Nowelizacja kodeksu pracy obowiązująca od 23 sierpnia 2013 r. wprowadziła tzw. elastyczny czas pracy. Ustawodawca przyjął, że w każdym systemie czasu pracy, okres rozliczeniowy może być przedłużony, nie więcej jednak niż do 12 miesięcy, przy zachowaniu ogólnych zasad dotyczących ochrony bezpieczeństwa i zdrowia pracowników. Ustawodawca zastrzegł, jednocześnie że powinno to być oczywiście uzasadnione przyczynami obiektywnymi lub technicznymi bądź dotyczącymi organizacji pracy. Użyty w art. 129 § 1 zwrot „czas pracy nie może przekraczać”, wskazuje, iż regulacja ma charakter ochronny, polegający z jednej strony na tym, że normy te nie mogą być w żadnym przypadku wydłużane chyba, że przepisy kodeksu pracy lub przepisy odrębne wyraźnie na to zezwalają, z drugiej strony pojawia się możliwość skrócenia tych norm ${ }^{14}$.

${ }^{13}$ T. Nycz, Wybrane problemy przepisów o czasie pracy, Praca i Zabezpieczenie Społeczne 5(2000), s. 27-28.

${ }^{14}$ Z. SAlwa, Kodeks pracy. Komentarz, Warszawa 2003, s. 449. 
Artykuł 129 kodeksu pracy ustanawia pięciodniowy tydzień pracy. Według Tadeusza Nycza można potraktować to jako późną odpowiedź na żądania robotników z sierpnia 1980 r., którzy domagali się wprowadzenia wszystkich sobót wolnych od pracy. Jednakże reguła pięciodniowego tygodnia pracy nie daje pracownikom prawa do wszystkich sobót wolnych od pracy. Zasada ta oznacza jedynie, iż proces pracy może być realizowany tylko przez pięć dni w tygodniu ${ }^{15}$. Najbardziej znanym rozwiązaniem jest tydzień pracy, obejmujący pięć dni od poniedziałku do piątku. Nie oznacza to, że jest to jedyne poprawne rozwiązanie, ponieważ tydzień pracy może rozpoczynać się na przykład we wtorek, a kończyć w sobotę. Można także ustalić tydzień czasu pracy od poniedziałku do soboty z wolnym dniem w połowie tygodnia. Dzień ten może podlegać zmianie, uzależnione jest to od konkretnych ustaleń ${ }^{16}$.

$\mathrm{Na}$ tle regulacji tej zasady powstały dwa zasadnicze pytania: czy zasada pięciodniowego tygodnia pracy odnosi się do wszystkich systemów czasu pracy oraz czy zasada ta oznacza, że każdy tydzień pracy ma składać się najwyżej z pięciu dni pracy? Odpowiadając na pierwsze pytanie, trzeba podkreślić, iż art. $129 \S 1$ ma charakter wiodący i ustala reguły obowiązujące w odniesieniu do wszystkich rodzajów czasu pracy, odstępstwa od niego muszą mieć charakter wyraźny ${ }^{17}$. Do niedawna kontrowersyjne było zagadnienie prawne poruszone $\mathrm{w}$ drugim pytaniu, a mianowicie, czy zasada pięciodniowego tygodnia pracy bezwzględnie oznacza, iż w każdym tygodniu pracownik może być zobowiązany do pracy nie więcej niż przez pięć dni. Na pierwszy rzut oka, analizując zwrot zawarty w dawnym art. $129 \S 1$ kodeksu pracy, że przewidziane w nim normy czasu pracy odnoszą się do pięciodniowego tygodnia pracy sugerowałoby, iż każdy tydzień roboczy składać się może, co najwyżej z pięciu dni pracy. Jednak w takiej sytuacji bezprzedmiotowe byłoby postanowienie o przeciętnej 40 - godzinnej normie tygodniowej, ponieważ praca w każdym tygodniu przez maksimum pięć dni oznaczałaby, że norma tygodniowa czasu pracy nigdy

\footnotetext{
${ }^{15}$ Por. T. Nycz, Nowe przepisy o czasie pracy - artykut dyskusyjny, Praca i Zabezpieczenie Społeczne 6(2001), s. 24.

${ }^{16}$ A. M. ŚwiątKowsKi, Komentarz do kodeksu pracy, Kraków 2002, s. 630.

${ }^{17}$ Por. M. BARzycKa-BanaszczyK, Kodeks pracy. Komentarz, Warszawa 2002, s. 272.
} 
nie przekroczyłaby 40 godzin. Dlatego przewidziana 40 godzinna norma miałaby wtedy sztywny, a nie przeciętny charakter. Z powyższych rozważań łatwo można wnioskować, że „pięciodniowy tydzień pracy” jest tygodniem przeciętnym dla danego okresu rozliczeniowego. Oznacza to, iż w jednym tygodniu pracownik może być zobowiązany do pracy w ciągu sześciu dni, ale w kolejnym tygodniu może pracować jedynie przez cztery dni ${ }^{18}$. Ustawodawca wyraźnie przecież podkreślił, że chodzi o przeciętnie pięciodniowy tydzień pracy.

Kodeks pracy dopuszcza skracanie norm czasu pracy przewidzianych w art. 129, czyli ośmiogodzinnej normy dobowej oraz przeciętnej czterdziestogodzinnej normy w przeciętnie pięciodniowym tygodniu pracy. Możliwość taka istnieje, jeśli wystąpią szczególnie uciążliwe lub szczególnie szkodliwe dla zdrowia warunki pracy ${ }^{19}$. Zgodnie z art. 145 kodeksu pracy skrócenie czasu pracy poniżej obowiązujących podstawowych norm, dla pracowników zatrudnionych w warunkach szczególnie uciążliwych lub szczególnie szkodliwych dla zdrowia może polegać na ustanowieniu przerw w pracy wliczanych do czasu pracy bądź też na obniżeniu tych norm. Przypadek pracy monotonnej lub pracy $\mathrm{w}$ ustalonym $\mathrm{z}$ góry tempie polega na wprowadzeniu przerw $\mathrm{w}$ pracy wliczanych do czasu pracy ${ }^{20}$.

Wielu pracowników korzysta ze skróconego czasu pracy. Dzieje się tak bądź to z uwagi na konstrukcję fizyczną i właściwości fizjologiczne osoby, bądź też z uwagi na wzmożony wysiłek wynikający ze szkodliwych lub uciążliwych warunków pracy albo charakteru i rodzaju wykonywanego zatrudnienia ${ }^{21}$.

Główną przyczyną wprowadzenia w prawie skróconego czasu pracy jest występowanie w środowisku pracy czynników szczególnie szkodliwych bądź szczególnie uciążliwych dla zdrowia pracowników. Szkodliwe warunki pracy mogą polegać zwłaszcza na działaniu sub-

${ }^{18} \mathrm{~K}$. RĄCZKA, Czas pracy - nowa regulacja prawna, Praca i Zabezpieczenie Społeczne 4(2001), s. 25; Zob. T. Nycz, Glosa do uchwały składu siedmiu sędziów Sądu Najwyższego z 14 listopada 2001 r. III ZP 20/01, Praca i Zabezpieczenie Społeczne 10(2003), s. 34-39.

${ }^{19}$ Z. SALwA, Kodeks pracy. Komentarz, s. 474.

${ }^{20}$ Zob. K. JaŚKowski - E. Maniewska, Kodeks Pracy. Komentarz, s. 371-372.

${ }^{21}$ Z. Salwa, Prawo pracy i ubezpieczeń społecznych, Warszawa 2003, s. 214. 
stancji trujących, promieniotwórczych, używaniu urządzeń udarowych, jak również na stykaniu się z czynnikami rakotwórczymi ${ }^{22}$.

Pracą szczególnie uciążliwą jest praca, której rodzaj albo sposób wykonywania wpływa ujemnie na stan psychofizyczny pracownika. Efektem końcowym jest jego nadmierne lub zbyt szybkie zmęczenie. Jako przykład takich prac można podać prace polegające na wykonywaniu żmudnych, wymagających dużej koncentracji czynności ${ }^{23}$.

Prace monotonne to prace jednostajne, które polegają na wykonywaniu tych samych lub ograniczonych przedmiotowo czynności, co powoduje u pracownika stan znużenia. W przypadku prac wykonywanych w ustalonym z góry tempie, pracownik nie ma wpływu na ich rytm, który jest zdeterminowany stosowaną organizacją procesu pracy, zwłaszcza procesu produkcji. Jako przykład można wskazać na pracę wykonywaną przy taśmie produkcyjnej sterowanej komputerowo ${ }^{24}$.

Sławomir Driczinski, w związku z instytucją skróconego czasu pracy, zwrócił uwagę, że trzeba rozdzielić dwa pojęcia: „skrócony czas pracy” oraz „skracanie czasu pracy”. To ostatnie pojęcie jest wyrazem ogólnej tendencji do skracania czasu pracy. Trzeba podkreślić, iż skrócony czas pracy nie jest fragmentem skracania czasu pracy w ogólności. Zdarza się, że obydwa trendy osiągają podobny efekt, zachodzi też możliwość wykorzystywania skróconego czasu pracy jako narzędzia do skracania czasu pracy w ogólności. Jednak nie zmienia to odrębności instytucji skróconego czasu pracy ${ }^{25}$.

\section{Czas pracy pracowników młodocianych}

Warto wspomnieć o szczególnej kategorii pracowników, wyodrębnionej z uwagi na wiek, a mianowicie pracowników młodocianych. Praca ich jest chroniona przez normy prawne, które kształtują status

${ }^{22}$ J. RomAŃczUK, Skrócony czas pracy przy pracach szkodliwych lub szczególnie uciażliwych dla zdrowia pracowników, Praca i Zabezpieczenie Społeczne 6(1999), s. $32-33$.

${ }^{23}$ M. BarzycKa-BANASZczyK, Kodeks pracy. Komentarz, s. 284.

${ }^{24} \mathrm{~K}$. RączKa, Systemy czasu pracy w znowelizowanym kodeksie pracy, Praca i Zabezpieczenie Społeczne 2(2004), s. 17.

${ }^{25}$ S. DRICZINSKI, Skrócony czas pracy - niektóre problemy i propozycje rozwiązań, Praca i Zabezpieczenie Społeczne 3(2000), s. 9-10. 
pracowniczy tej kategorii zatrudnionych korzystniej w porównaniu z ogółem pracowników oraz przez normy, które nakładają na pracodawców specjalne obowiązki, związane z zatrudnianiem młodocianych. Młodocianym w rozumieniu kodeksu pracy jest osoba, która ukończyła 16 lat, a nie przekroczyła 18 lat. Zasadniczo dopuszczalne jest zatrudnianie jedynie tych młodocianych, którzy ukończyli co najmniej gimnazjum, a jednocześnie przedstawią świadectwo lekarskie stwierdzające, że praca danego rodzaju nie zagraża ich zdrowiu. Jeśli młodociany nie posiada kwalifikacji zawodowych, może on być zatrudniony jedynie $\mathrm{w}$ celu przygotowania zawodowego ${ }^{26}$. W innym celu niż przygotowanie zawodowe, młodociany może być zatrudniony na podstawie umowy o pracę przy wykonywaniu prac lekkich. Praca lekka nie może powodować zagrożenia dla życia, zdrowia i rozwoju psychofizycznego młodocianego, a dodatkowo nie może także utrudniać młodocianemu wypełniania obowiązku szkolnego. Przejawem troski ustawodawcy o stan zdrowia młodocianych są przepisy dotyczące wprowadzenia obowiązku poddawania młodocianych badaniom lekarskim, zapewnienia wypoczynku przez ograniczenie czasu pracy młodocianych oraz zakazujące zatrudniania młodocianych przy pracach im wzbronionych ${ }^{27}$.

W porównaniu z normami powszechnie obowiązującymi dzienne normy czasu pracy młodocianych zostały skrócone i dostosowane do ich wieku. Czas pracy młodocianego, w związku z koniecznością ochrony słabszego organizmu, jest ograniczony. Zgodnie z art. 202 kodeksu pracy, w przypadku osoby, która nie ukończyła 16 lat, wynosi on nie więcej niż 6 godzin na dobę (dotyczy to również sytuacji, gdy młodociany jest zatrudniony u więcej niż jednego pracodawcy). Młodociani w wieku powyżej 16 lat nie mogą pracować więcej niż 8 godzin na dobę. Jednak trzeba podkreślić, iż efektywnie czas pracy młodocianych jest krótszy, ponieważ wlicza się doń czas nauki i to bez względu na to czy odbywa się ona w godzinach pracy, czy poza

${ }^{26}$ K. W. Baran (red.), Prawo pracy i ubezpieczeń spolecznych, Warszawa 2013, S. 467.

${ }^{27}$ T. ZIELIŃSKI, Kodeks pracy. Komentarz, s. 980. 
nimi $^{28}$. Jeżeli dobowy wymiar czasu pracy młodocianego jest dłuższy niż 4,5 godziny, pracodawca jest zobowiązany wprowadzić przerwę w pracy trwającą nieprzerwanie 30 minut, wliczoną do czasu pracy. Tygodniowy wymiar czasu pracy młodocianego w okresie odbywania obowiązkowych zajęć szkolnych nie może przekraczać 12 godzin. Ponadto pracodawca musi pamiętać, że w dniu odbywania zajęć szkolnych wymiar czasu pracy pracownika młodocianego nie może przekraczać 2 godzin (dotyczy to także sytuacji, gdy młodociany zatrudniony jest u kilku pracodawców). Wymiar czasu pracy młodocianego w okresie ferii szkolnych nie może przekraczać 7 godzin na dobę i 35 godzin w tygodniu.

Artykuł 204 kodeksu pracy wprowadza zakaz zatrudniania młodocianych przy pracach wzbronionych, których wykaz ustala Rada Ministrów w porozumieniu ze związkami zawodowymi. Zakaz odnosi się do wszystkich młodocianych, zarówno zatrudnionych w celach zarobkowych, jak i w celu przygotowania zawodowego. Ponadto ustawodawca przewidział zakaz zatrudniania młodocianych w godzinach nadliczbowych oraz w porze nocnej. Odpoczynek tygodniowy młodocianych został określony w art. $203 \S 3$ kodeksu pracy. Zgodnie z tym przepisem, mają oni prawo do nieprzerwanego odpoczynku w każdym tygodniu, przez co najmniej 48 godzin, obejmującego niedzielę. Oznacza to, iż ustawodawca wykluczył możliwość zatrudniania młodocianych w niedzielę ${ }^{29}$.

\section{Limit pracy w godzinach nadliczbowych}

Ustawodawca w art. $151 \S 1$ zdefiniował pracę w godzinach nadliczbowych, stanowiąc, iż jest nią praca wykonywana ponad obowiązujące pracownika normy czasu pracy, jak również praca wykonywana ponad przedłużony dobowy wymiar czasu pracy, który wynika z obowiązującego pracownika systemu i rozkładu czasu pracy ${ }^{30}$. Za-

${ }^{28}$ M. Barzycka-BanaszczyK, Prawo pracy, Warszawa 2004, s. 291.

${ }^{29}$ K. JAŚKOWSKI - E. MANIEWSKA, Kodeks pracy. Komentarz, s. 450.

${ }^{30} \mathrm{~K}$. RĄCZKA, Nowe pojęcie pracy $w$ godzinach nadliczbowych, Praca i Zabezpieczenie Społeczne 3(2004), s. 24; Zob. M. Pliszkiewicz, Pojęcie pracy w godzinach nadliczbowych, Państwo i Prawo 11(1973), s. 105. 
tem pracą nadliczbową jest nie tylko praca przekraczająca wyznaczoną pracownikowi w danej dobie pracowniczej normę czasu pracy wyższą niż 8 godzin, o czym przepis wyraźnie stanowi, ale również praca przekraczająca wyznaczony dobowy wymiar czasu pracy niższy niż $8 \operatorname{godzin}^{31}$. Jest to wykonywanie pracy ponad normę dobową czasu pracy: normalną, skróconą lub wydłużoną ${ }^{32}$. W myśl nowych przepisów, które ustawodawca wprowadził w związku z tzw. elastycznym czasem pracy warto także pamiętać, że nie stanowi pracy w godzinach nadliczbowych czas odpracowania zwolnienia od pracy, udzielonego pracownikowi, na jego pisemny wniosek, w celu załatwienia spraw osobistych. Jednakże odpracowanie zwolnienia od pracy nie może naruszać prawa pracownika do odpoczynku dobowego i tygodniowego.

$\mathrm{Z}$ uwagi na fakt, iż praca $\mathrm{w}$ godzinach nadliczbowych wydłuża czas pracy pracownika, ujęta została w ścisłe ramy prawne, a korzystanie z niej uzależnione zostało od spełnienia określonych warunków. Jest ona dopuszczalna wyłącznie wtedy, gdy zezwalają na to przepisy kodeksu pracy. Ustawodawca stanowi, iż praca taka jest możliwa w dwóch grupach przypadków. Po pierwsze w razie konieczności prowadzenia akcji ratowniczej dla ochrony życia lub zdrowia ludzkiego albo dla ochrony mienia lub środowiska, albo usunięcia awarii. Po drugie, gdy zarządzenia takiej pracy wymagają szczególne potrzeby pracodawcy $^{33}$. Pierwszy z tych przypadków został dość ściśle określony i dotyczyć może takich sytuacji jak: pożar, powódź czy awaria maszyn i urządzeń. Ze względu na charakter sytuacji wymagających kontynuowania pracy, liczba godzin nadliczbowych przepracowanych z tych powodów nie jest limitowana. Praca w godzinach nadliczbowych jest wykonywana w warunkach określonego zmęczenia pracownika. Dlatego też już w drugiej grupie przypadków, a mianowicie w związku

${ }^{31}$ K. RĄCzKA, Praca $w$ godzinach nadliczbowych $w$ znowelizowanym kodeksie pracy, Praca i Zabezpieczenie Społeczne 1(2004), s. 13; Zob. M. Gersdorf, O pojęciu pracy $w$ godzinach nadliczbowych polemicznie, Praca i Zabezpieczenie Społeczne 3(2004), s. 22-23.

${ }^{32}$ T. Nycz, Wynagrodzenie za pracę w godzinach nadliczbowych, Praca i Zabezpieczenie Społeczne 7-8(2000), s. 39.

${ }^{33}$ A. M. ŚwiątKowski, Elementy prawa pracy, Warszawa 2003, s. 190-191; Zob. A. Stefaniak, Kodeks Pracy. Komentarz, Warszawa 2003, s. 306. 
z wystąpieniem szczególnych potrzeb pracodawcy, zgodnie z art. 151 $\S 3$ kodeksu pracy, liczba godzin nadliczbowych została ograniczona do 150 godzin w roku kalendarzowym dla poszczególnego pracownika ${ }^{34}$. Warto podkreślić, iż w ramach szczególnej ochrony zdrowia pracowników młodocianych, zgodnie z art. $203 \S 1$ kodeksu pracy, istnieje bezwzględny zakaz zatrudniania ich w godzinach nadliczbowych i w porze nocnej.

Podstawowym warunkiem, aby móc uznać pracę, za pracę w godzinach nadliczbowych jest jej wykonywanie. Dlatego też pracownik nie może czekać w gotowości na polecenie przełożonego, ale powinien pracę faktycznie wykonywać, niezależnie od rodzaju wykonywanej pracy. Nie ma zatem istotnego znaczenia czy praca ta będzie zgodna z umową o pracę, czy obowiązkami pracownika ${ }^{35}$.

Wykonywanie pracy w czasie przekraczającym obowiązujące pracownika normy czasu pracy, musi zostać odpowiednio zrekompensowane temuż pracownikowi, najczęściej w postaci dodatkowego wynagrodzenia. Zgodnie $\mathrm{z}$ art. $151^{1} \mathrm{za}$ pracę nadliczbową przysługuje normalne wynagrodzenie za czas pracy nadliczbowej powiększone o wynagrodzenie dodatkowe ${ }^{36}$. Pojęcie normalnego wynagrodzenia za pracę w godzinach nadliczbowych obejmuje wynagrodzenie zasadnicze, które wynika ze stawki osobistego zaszeregowania, jak również wypłaty stanowiące faktyczne zwiększenie tej stawki, czyli m. in. dodatek funkcyjny, czy dodatek za pracę w porze nocnej. W rozumieniu art. $151^{1} \S 1$ pojęcie normalnego wynagrodzenia obejmuje jedynie te elementy składowe systemu płacowego, które są stałe w sensie przysługiwania w każdym z odpowiednich okresów swego obliczenia, ale równocześnie są one niestałe pod względem ich wysokości, zależnej od liczby godzin wykonywania pracy ${ }^{37}$.

${ }^{34}$ Por. A. M. ŚwiątKowski, Polskie prawo pracy, Warszawa 2003, s. 381; Zob. K. Kolasiński, Prawo pracy i ubezpieczeń społecznych, Toruń 1997, s. 241-243.

${ }^{35}$ G. ZDZIENNICKA - KACZOCHA, Węzłowe zagadnienia zwiazane z czasem pracy, Skierniewice 1997, s. 28.

${ }^{36}$ A. Kosut, Praca w godzinach nadliczbowych i jej wynagradzanie, Praca i Zabezpieczenie Społeczne 5(1998), s. 31.

${ }^{37}$ A. KIJOwski, Pojęcie normalnego wynagrodzenia za prace $w$ godzinach nadliczbowych, Praca i Zabezpieczenie Społeczne 10(1996), s. 36. 
Pracodawca ma jednak wybór i może rekompensować pracownikowi pracę w godzinach nadliczbowych w dwojaki sposób albo poprzez dodatkowe wynagrodzenie, albo czasem wolnym od pracy. Udzielenie czasu wolnego od pracy w zamian za pracę w godzinach nadliczbowych może mieć miejsce albo na wniosek pracownika, albo bez takiego wniosku z inicjatywy pracodawcy. Jednakże w drugiej sytuacji, jak mówi art. $151^{2} \S 2$, czasu wolnego udziela się w wymiarze o połowę wyższym niż liczba przepracowanych godzin nadliczbowych, co nie może spowodować obniżenia wynagrodzenia należnego pracownikowi za pełny miesięczny wymiar czasu pracy ${ }^{38}$.

Warto podkreślić, iż pracownik ma obowiązek wykonać pracę w godzinach nadliczbowych, jeśli tylko, została ona mu zlecona zgodnie z przepisami prawa i postanowieniami umowy. W wyroku z 16 grudnia 1987 r. I PRN 68/87 Sąd Najwyższy wskazał, iż praca w godzinach nadliczbowych jest wykonywana w warunkach określonego już zmęczenia pracownika. Nie uzasadnia to jednak odmowy pracownika wykonania polecenia pozostania poza godzinami pracy w celu zakończenia usuwania awarii, nawet jeżeli pracownik uważa, że niesłusznie został pozbawiony premii ${ }^{39}$.

Ustawodawca w kodeksie pracy dla ściśle określonych grup pracowników wprowadził zakaz pracy w godzinach nadliczbowych. Zakazy te można podzielić na bezwzględne, które obowiązują bez jakichkolwiek wyjątków oraz zakazy względne, obowiązujące w zakresie ograniczonym. Zakazy bezwzględne dotyczą kobiet w ciąży, pracowników młodocianych, pracowników niepełnosprawnych, pracowników posiadających zaświadczenie z zakładu opieki zdrowotnej o niemożności wykonywania takiej pracy, jak również pracowników zatrudnionych na stanowiskach pracy, na których występują przekroczenia najwyższych dopuszczalnych stężeń i natężeń czynników szkodliwych dla zdrowia, jeśli praca nadliczbowa podyktowana jest szczególnymi potrzebami pracodawcy. Wykaz szkodliwych czynników zawiera rozpo-

${ }^{38}$ M. Oleksyn, Czas pracy w praktyce, Warszawa 2003, s. 89, 95.

${ }^{39}$ Wyrok Sądu Najwyższego z 16 XII 1987, I PRN 68/87, OSNCAP nr 10/1990, poz. 164. 
rządzenie Ministra Pracy i Polityki Socjalnej z dnia 6 czerwca 2014 r. w sprawie najwyższych dopuszczalnych stężeń i natężeń czynników szkodliwych dla zdrowia w środowisku pracy ${ }^{40}$. Zakazy względne odnoszą się do osób opiekujących się dzieckiem w wieku do lat czterech, to znaczy wymagana jest wówczas wyraźna zgoda takiego pracownika na zatrudnienie go w godzinach nadliczbowych.

\section{Zakończenie}

Formalnie rzecz ujmując pojawia się zjawisko skracania czasu pracy. Gwarancje związane z odpoczynkiem rozbudowują się. Prawo do wypoczynku wyrażają przepisy o czasie pracy. Przewidują pracownikom - co do zasady - nie dłuższy niż 8 godzinny dzień pracy i przeciętnie 40 godzinny tydzień pracy, płatną przerwę w pracy, wypoczynek dobowy i tygodniowy, a także ograniczenie pracy w godzinach nadliczbowych, w niedzielę i święta. Wydawałoby się, że jest to duży postęp, ale z drugiej strony dzięki nowym technologiom, zacierają się granice między czasem pracy a czasem wypoczynku. Powstaje pytanie czy rzeczywiście można mówić o znacznym postępie? Dzięki nowym technologiom, np. powszechnym już dziś telefonom komórkowym, pracownik jest dla pracodawcy dostępny przez całą dobę. Rozwiązanie tego problemu nie jest łatwe. Zagadnienie wymaga dokładnej analizy, która pomoże znaleźć sposób, aby pracownik mógł rzeczywiście odpocząć.

Wysiłek zarówno fizyczny, jak i umysłowy, w pracy przekraczającej 8 godzin na dobę staje się w miarę zwiększania zmęczenia coraz bardziej uciążliwy, nawet przy pracy lekkiej. Skutki zmęczenia są gorsze przy pracach w wymuszonej pozycji ciała, a także przy wykonywaniu czynności skomplikowanych. Bez wątpienia w ostatnich godzinach pracy pracownicy są szczególnie podatni na wypadki przy pracy oraz zwiększony stres ${ }^{41}$.

Wypoczynek służy przede wszystkim regeneracji sił pracownika. Aby pracownik, mógł efektywnie wypełniać ciążące na nim obowiąz-

\footnotetext{
${ }^{40}$ Dz. U., poz. 817.

${ }^{41}$ T. Nycz, Ochronny charakter przepisów o czasie pracy - wybrane zagadnienia, Praca i Zabezpieczenie Społeczne 3(1999), s. 3.
} 
ki, nie może być zmęczony. Wzrost objawów zmęczenia, czyli spadek zdolności do pracy wynika $\mathrm{w}$ znacznym stopniu $\mathrm{z}$ niedostatecznego odpoczynku. Dlatego zasadne i ważne jest przyznanie i wykorzystywanie prawa do wypoczynku.

\section{Daily and weekly rest periods}

In the article issues of the daily and weekly rest periods of rest were addressed in the light of provisions of the labour law. The legislator in the Labour Code has implemented regulations that guarantee periods of rest. The employee is entitled to the time of rest in order to be able to effectively perform one's duties. Therefore during every twenty-four hours the employee has the right to at least 11 consecutive hours of the rest. However the weekly rest periods should include at least 35 hours, including at least 11 consecutive hours of daily rest period. If daily dimension of employee's work amounts to at least 6 hours, then he is entitled to 15 minutes of the break included in working hours.

Work performed in the overtime, extends working hours of the worker and therefore the legislator clearly determined conditions which must be fulfilled to use this institution. Overtime work should be compensated to an employee through additional remuneration of compensatory rest period. Working hours of young workers comparing to working hours of adult workers were shortened and adapted for their age and the young organism that needs more rest. Also a time of the learning is included in working hours of young workers therefore effectively their working hours are shorter than of remaining employees.

SŁowa KLUczowE: czas pracy, odpoczynek dobowy, odpoczynek tygodniowy

KEY WORDS: working time, daily rest, weekly rest 